\title{
Postscript. Interdisciplinary Dialogue And Lucknow's Cultural System
}

Sandria Freitag

\section{OpenEdition}

\section{Journals}

\section{Electronic version}

URL: http://journals.openedition.org/samaj/3949

DOI: 10.4000/samaj.3949

ISSN: $1960-6060$

\section{Publisher}

Association pour la recherche sur l'Asie du Sud (ARAS)

\section{Electronic reference}

Sandria Freitag, «Postscript. Interdisciplinary Dialogue And Lucknow's Cultural System », South Asia Multidisciplinary Academic Journal [Online], 11 | 2015, Online since 15 July 2015, connection on 21 April 2019. URL : http://journals.openedition.org/samaj/3949 ; DOI : 10.4000/samaj.3949

This text was automatically generated on 21 April 2019

\section{(c) (i) (9)}

This work is licensed under a Creative Commons Attribution-NonCommercial-NoDerivatives 4.0 International License. 


\title{
Postscript. Interdisciplinary Dialogue And Lucknow's Cultural System
}

\author{
Sandria Freitag
}

\section{Introduction}

Does Lucknow 'suffer' from 'too much history' as the informant commented to our editors? This postscript suggests that, however far the city may have moved from its Nawabi beginnings, the inherited strategies that shaped Lucknow's cultural system under the Nawabs made space for its residents to play an active role in defining that system. This contribution is fundamental to understanding life in this urban central place over more than two centuries: the inclusiveness essential to claiming legitimacy by a Successor State in its locality also provided the flexibility and authority for the cultural system to respond creatively to new challenges as its historical context changed. At the heart of our narrative, then, lie the strategies inherent not only in the Nawabs' approach to their kingdom, but in the larger implications for contemporary India of a Successor State's creation of an inclusive and responsive cultural system shaped by the agency of its residents.

Given that the key elements in a cultural system-that set of practices and collective cultural expressions that add up to a distinctive modality-provide a range of sociopolitical, cultural, and economic attributes that are approached in complementary if distinctive ways by the disciplines of history and anthropology, this collection of essays has provided an ideal entry point for understanding the Successor State cultural system operating in Lucknow. The re-emergence over time of key issues in their changing guises helps to chart characteristic practices and dynamics essential for this place. Here, despite the constraints on depth and length inherent in a 'postscript', I'd like to suggest the ways in which this distinctiveness delineates the outlines of a larger pattern. 
Jones' essay in this collection has provided background to Abdul Halim Sharar's potent (if nostalgic) description of the cultural system associated with the Nawabi Successor State. Particularly apt for our purpose is Sharar's comment that

Outwardly the court of Lucknow became so magnificent that no other court could rival it and the town of Lucknow acquired great splendor. The money which Shujaud-Daula had spent on the army and on provision for war, Asaf-ud-Daula started to spend in satisfying his desire for voluptuous living and on the embellishment and comforts of the town. In a short time he had collected to himself all the pomp and splendor that could be found in the world. His one desire was to surpass the Nizam of Hyderabad and Tipu Sultan and his ambition was that the magnificence and grandeur of no court should equal that of his own. (Sharar 1975: 44-5)

Sharar's chapter continues by listing the building program of Asaf-ud-Daula, the fourth Nawab of Awadh, who moved the capital city from Faizabad to Lucknow in 1775, and so had a relatively clean slate on which to 'construct' both a cultural system and the urban built environments that conveyed this Successor State's identity. As compared to nearby Banaras (or Varanasi), for instance, Lucknow was a very different kind of city, designed to be a political capital for a different style of rule: the Nawabs were a Persian Shia Muslim dynasty, and used their Shi'ism to call out distinctive elements as markers of their cultural system, while also becoming known for their inclusiveness and even 'secular' characteristics of rule (marked, for instance, by their patronage of Basant [kite festival] and even acting the part of Krishna in courtly theatre). At the same time, the Nawabs could use their reliance on Persian to attract poets and other artists previously resident in Delhi to move to Lucknow; indeed, poetry became the most prominent marker of court culture in Lucknow.

5 As observed by Jones, Sharar wrote at the turn of the century, and rode a wave of nostalgia for that Nawabi cultural system that had dominated the city for the preceding century and a half. We might note two revealing aspects of Sharar's description: first, his language adopts the British tone of denigration (e.g., 'voluptuous', 'pomp'), which reflects the political changes under which Sharar wrote: Sharar accepts the characterizations and blame placed on the Nawabs by the British. A second revealing aspect of the quotation, however, is the frame of reference Sharar presents: for the Nawabs (as for Sharar?), it is the Successor States, and only those ruled by the Nizam of Hyderabad and Tipu Sultan of Mysore, that the Nawab wants to 'surpass'. The neighbouring Rohillas (the closest kingdom) are only worth mentioning because they are so uncivilized that everyone moves on quickly to Lucknow; other princely states emerging in the South and West are not mentioned; and the East India Company lands are, apparently, also too uncivilized to be considered. Moreover, the Mughals present neither the standard to measure against nor even an appropriate comparison.

6 These revealing contexts for Sharar's description of the city point the way to the argument that frames our treatment. As the capital of the Successor State of Awadh, Lucknow became the centre of a new kind of rule and expectations for a cultural system that was distinctive both from what had gone before, and from what the encroachment of British/ European 'modernism' represented. One of the most significant embodiments of this new mode was the Nawabi building programme, a topic little considered in this collection. Nevertheless, a form of 'visual history' is a most compatible partner with ethnography, as I hope the remainder of this postscript will attest. As Sharar comments about Asaf-ud-Daula's buildings, they are [asserted to be] 'nothing like the Mughal Emperor's stone buildings... [they] have a rare beauty and great dignity and distinction... 
[moreover, they] are in no way influenced by European architecture. In style they are purely Asiatic, without ostentation but with genuine splendor and dignity' (Sharar 1975, 47).

This helps us to see the importance of built environments for shaping a place, not least by creating a long-lasting physical context, and for serving as the way that new claimants to civilizational significance could put their mark on the city. The buildings thus helped to outline characteristic patterns of similar Successor States, including a distinctive space created for the state's 'public' and popular participation. That is, this cultural system's components point us to what was most valued in this urban place over time (for instance, other functions related to these key buildings) and served to tie the royal house to popular culture and the urban population. While the Nawabs' motivation was to demonstrate their authority and legitimacy through this strategy, it also made a space for popular as well as elite shaping of the new cultural system and its capital city. ${ }^{1}$ In the process, it established precedents and processes that helped shape participants' responses to changes and challenges over time. Indeed, interactions of bodies and buildings in everyday life as well as ritual events lie behind several of the occasions investigated in the essays in this volume (e.g., those by Jones, Hong Tschalär, and Susewind).

\section{Lucknow's Cultural System}

8 As with all these Successor State rulers-not least those with whom the Nawabs compared themselves-creating a local system with legitimacy depended on a Janus-like function that situated these regional kingdoms in a distinctive way. On the one hand, they linked their authority to a relationship with the greater sources of rule-here represented by the Mughals-while trying to increase their distance and hence independence from these sources. On the other hand, they located their legitimacy in part by connecting to what the local population valued, especially through activities staged in public spaces. A focus on public devotional activities enabled the implicit connection between local religious understandings of devotion and loyalty to the royal house. The strategy of facing two ways to claim authority and legitimacy, then, set up Successor States to create cultural systems that also possessed a crucial flexibility, enabling them to adjust as circumstances altered the larger context in which they operated (e.g., from Mughal to British rule, and then to independence in the mid-20 $0^{\text {th }}$ century). It also made space for adjustments to local changes of leadership and influence, and related claims to power, among the local populace. One of the strong suits of this essay collection are the examples provided of recent adjustments, including the agency exercised through Dalit strategies, Muslim middle-class negotiations, and the range of enacted claims to women's empowerment.

9 Serving as patrons of a wide range of cultural activities, the Nawabs could direct public activities towards Shia narratives to put a distinctive stamp on the resulting cultural system. In this way, they pursued the same strategies as the Sharar-cited comparison Successor States as well as closer competitors, such as the Raja of Banaras (a comparison to which we will return). The central events of the Shia narrative, focused on the battle for leadership at Karbala during the month of Muharram, thus came to frame many of the public aspects of the Nawabs' cultural system. of Husain during the Karbala battles. Asaf-ud-Daula established the shrine, and virtually 
every Nawab to follow added to the complex. The popular appeal of the shrine can be measured not only by the practice that arose of bringing the alams paraded during Muharram to be blessed by the saint, but also attendance at the kitchen established by Malka Zamani (favourite queen of Naseer-ud-din Haider, r. 1827-37), distributing free food to the poor.

The propensity for processions-whether the mourning processions wending their city way over the ten days of Muharram observances, royal processions, or other processions enacting additional stories and devotional activities-fundamentally shaped the layout of Nawabi Lucknow. As the processions either proceeded in boats down the river Gomti, or along a wide avenue paralleling the river, they passed increasing numbers of significant royal-sponsored buildings that punctuated the cityscape with palaces, imambaras, gates (most notably the Rumi Darwaza), mosques, even the Residency built to house the representative of the East India Company. Establishing the edges of this universe were Karbala grounds, to which the tazias (tomb replicas) were taken during Muharram processions for 'burials'. The purposes of these built environments helped to convey the cultural system being established: imambaras represented not only the elaborate and highly illuminated buildings in which the permanent tazias were stored and displayed year-round, but their large, open rooms also hosted the crowds who attended majalis twice-daily to lament and to hear sermons, as well as nightly instalments of the Karbala story. ${ }^{2}$ They served discrete audiences for the majalis; such gatherings could tell quite different versions of the Karbala story and so accommodate a wide range of participants and their understandings of the narrative. Imambaras also came to be the staging centres for poetry readings cum contests, marking the high status accorded to this literary form in Lucknow's cosmopolitan culture. Finally, imambaras could be built not only for these purposes but to serve as private tombs for wealthier families. Taking such purposes altogether, the imambaras may thus reveal much to us about various associations attached to the families, neighbourhoods and social groupings who shared distinct viewpoints, values, and responses to particular leaders, and who made up the social fabric of Lucknow.

Collective life, then, as expressed through processions and other public observances that underscored shared experiences, along with discrete gatherings that enabled differing understandings, fostered an inclusive cultural system within the social hierarchies common to the time. This was essential, since Shias were and remain a minority even in Lucknow, and the royal emphasis on Shi'ism gave it a particular and unusual bent (that is by using a minority culture often focused on martyrdom to express what was meant to be an inclusive and majoritarian cultural system ${ }^{3}$ ). During the Nawabi period, inclusiveness took public-space expressions in which other residents participated in large numbers, often through particular kinds of alliances: e.g., Shias and Kayasths had affinities connected to executive and financial administration and cultural expressions; Sunnis, Baniyas and others dominated the economic life of the city. Lower-class/caste Hindus participated in the mourning culture as well, drawing parallels and seeing similarities through devotional practices as well as being situated within socio-economic interdependencies. One British observer, Emma Roberts, commented in 1835, for instance, that 'A very large proportion of Hindoos go into mourning during the ten days of Mohurrum, clothing themselves in green garments, and assuming the guise of fakeers' (Roberts 1835, 2:192-3). Reciprocally, Shias and Sunnis participated in ostensibly Hindu 
observances as well, and shared at least similar practices of devotionalism that fostered Lucknow's pride in cultural inclusivity.

Among the many intriguing complexities of the Nawabs' cultural system is the particular contribution made by women, which was connected in part to the emphasis on Shi'ism and to the place enabled for subcultures. For instance, the 1911 district gazetteer noted that two-thirds of those who identified themselves as Shi'as were women. Despite rulings by the Lucknow mujtahids against Sunni-Shi'a marriages, such marriages remained common, and the devotional culture of the women's quarter of a household could plausibly have perpetuated Shi'ism with relatively little interference from men. That many of the Muharram activities took place in gender-divided observances no doubt facilitated the perpetuation of this devotional culture. Shi'ism was especially popular among courtesans, perhaps in part because it offered legal protection for them by recognizing temporary marriage ( $m u t^{\prime}$ 'ah). Also, in part, however, it undoubtedly related to the nature of the alternative culture created by these women, characterized by scholar Veena Oldenburg as 'a style of non-confrontational resistance and packaged... not as a sporadic activity, but as a way of life' (Oldenburg 1990). This way of life, we should note, was based on economic independence as well as personalized religious devotionalism (where the combination often provided outlets for ostentatious display and patronage).

Different Karbala grounds also serve as markers for us of this complex cultural system and its impact on the changing map of Lucknow city. There were always multiple grounds, established for various reasons. But two in particular mark important moments in the history of the city. The main Karbala grounds during the Nawabi period were located towards the eastern part of the city, but were closed down after the 1857-58 Uprising, as the British reshaped the city with roads designed to move troops easily throughout, and took over the area abutting that eastern Karbala location to form the Civil Lines where the British would live. The relocated Karbala grounds moved to the south-western part of the city, where they functioned as the 'main' grounds until Shia reformist activity underscored the very different styles of observance between Shias and Sunnis; in 1906-08, the role of these particular Karbala grounds became problematized. We do not have space to outline these events, but want to draw attention to the fact that then, as in the more recent developments described in these essays, Lucknow's experiences reflected connections to changes in larger, external contexts. At the time, a major characteristic shared between Lucknow and other cities with disturbances was that these intra-community tensions then become routed through inter-sectarian conflicts. ${ }^{4}$ This intra-community pattern of conflict can be seen still, as Susewind's essay makes clear. Not least of the similarities with Susewind's case study is the fact that the early $20^{\text {th }}$ century conflict arose from the emergence of a reforming and fairly aggressive new middle-class Shi'i component who emphasized differing personal behaviour's as well as reworking of imambaras, and used these bases to assert new claims to leadership (Jones 2012). One result was a separation of karbalas for Sunnis and Shias, respectively, and the infusion of a measure of divisiveness into what had been an integrative enactment in public spaces.

\section{The Urban Context in Successor States}

15 Lucknow's role as capital city of the successor state of Awadh cannot be overstated; the Nawabs came to represent the Mughal system there. At the same time, Lucknow's history 
demonstrates the larger process of devolution of power and political authority to those in a region. The devolution of power and patronage also turns our attention to the urban centres emerging in this period of change.

Interest in the Indian urban place has enjoyed a renaissance in history as it has in anthropology (see Introduction). Influential case studies such as those by Will Glover, Nandini Gooptu, Janaki Nair and Swati Chattapodhyay, ${ }^{5}$ have all suggested the rich expansions possible through interdisciplinary approaches, especially those that connect the visual and spatial to the socio-political aspects of a city. In particular, this direction points to the possibilities opening up as historians explore the range of evidence informing locally contextualized identity-narratives and everyday life as aspects of significant historical patterns-where such new historiography no longer treats political developments as the only elements with explanatory power.

Perhaps most revealing for us, in this respect, is how Lucknow could be compared to Banaras/Varanasi (or 'Benares' as the British knew it). The Raja of Banaras, in his turn, was supposed to serve as tax collector for Awadh, and did make a tax payment each year to the Nawabs. He too worked hard to establish and maintain independence from this supposed overlord, and to a large extent succeeded (not least because the Nawabs' reach outside of Lucknow became increasingly tenuous the greater the distance from the capital city). In this independent stance, the Raja's actions were important primarily because they served as a kind of comparison and goad to the Nawabs' own efforts: both were intent on establishing cultural systems that worked within similar (though not identical) regional contexts. That is, just as the Nawabs created an inclusive system in which popular values, especially around devotionalism and enactments in public that could serve to connect people, so the Raja created new symbolic structures to express the Bhumihar Brahmin house of Narayan and its relationship with those it ruled. Both drew on the urban structures of mohullas (neighbourhoods), occupational networks, akharas ${ }^{6}$ and the like to link a devotional-style religion to the ruling house. These parallels led, not surprisingly, to a kind of cultural competition, in which Ramlila enactments expanded in the 19th century alongside the elaborations of Muharram nearby. The cities were also tied together in part by their differences in social composition: because Banaras lacked much in the way of upper-class Muslims, and this group occupied a relatively large social space as courtiers and other elites in Lucknow, the lower class Muslims of Banaras (most of whom were artisans otherwise tied to their upper caste Hindu 'paymasters') looked to Lakhnawi Muslims for leadership, advice and even a safety net not available in their own city. There were as well distinct differences, occasioned not least by different treatments by the British. ${ }^{7}$ Despite these differences, what was shared was a reliance on cultural patronage as a key element that underscored their authority in the creation of the two cultural systems. This was one of the strongest shared characteristics for Successor States in general. (Not least, it was one of the few avenues for rulers' actions left open as the British constrained them within the confines of 'indirect rule'.)

Cultural patronage, then, as an important aspect for both Successor State systems, was tied both to the patronage extended by the ruler himself, and to the range of cultural activities supported by courtier and literati participation and encouragement. Virtually all successor states, for instance, supported particular literary forms that also helped to develop regional languages and created critical masses of works within literary genres (especially poetry and literary criticism). These courts also had ateliers in their palaces for fine artists (painters, sculptors) and performers (musicians and dancers): their 
creations not only flattered the ruler and conveyed the stories of kings, gods, and key historical figures but provided material underpinnings to the cultural systems being developed. So too did the handicrafts of the region, which began to be consumed by the elite in each society: in Banaras this was marked especially by silk saris (the silk woven by Muslim weavers); in Lucknow it was chikan and other embroidery arts (involving zari, also primarily produced by Muslim craftspersons); local craft production thus could be used to undergird the local identities of these cities. Across these forms of cultural production, we see formative roles played by city dwellers in a wide range of socioeconomic positions, a key indicator of the agency operating within the cultural system.

Once again, these contributions relate to larger processes affecting popular participation in the Lakhnawi cultural system and in the formation and influence of a 'public' in the region. Efforts to inform and shape public opinion drew on what Bayly has called 'techniques of communication, debate and persuasion' emerging from Indian norms (Bayly 1996, chapter 5). These kinds of literary productions expressed through handwritten media 'the views of bazaar people and artisans' as well as the 'Hindustaniwriting literati. ${ }^{8}$ In this way, cultural inclusiveness reached across caste and class boundaries and laid significant groundwork for what was to come, even after the removal of the Nawabs. This form of language was 'inclusive; it mirrored and even stimulated the rapid social mobility which was characteristic of post-Mughal [that is, Successor State-era] north India' (emphasis added). Bayly goes on to note that this inclusiveness enfolded ordinary artisans, people of the bazaars, and women within various cultural-production fields. We see here, then, a first example of the Successor-State cultural-system flexibility that became so important for the more recent period studied in the ethnographic essays published here.

\section{Emerging Middle Classes and Lucknow's Cultural System}

In these ways the Successor States provided important intermittent historical 'moments' during which ideological identities could be created that bound them to their subjects and vice-versa. Not least important result of these functions was the ability developed in these places both to negotiate with the changes introduced by the British, and to utilize their cultural systems to create new expressions as well as to withstand or adapt in ways that made sense to city residents. These processes, shaping responses not only in the late $19^{\text {th }}$ century but in the following century as well, help to explain larger patterns of 'middleclassness' described in the essays included in this issue, and to connect to that 'Janus-faced' function elaborated by these Successor State cultural systems. The emerging flexible (even ambiguous) frames long outlived their originators. In Lucknow, that took a particularly striking form: the ruling house had been from an alternative form of Islam (later perceived as a minority within a minority), and yet had taken Shia traditions and adapted them to succeed as a powerful force at the apex of a socio-political hierarchy. The cultural system that the dynasty designed was so flexible it could survive a decline in those fortunes, and the exile of the house itself. What remained behind was a mode of social inclusiveness that, while requiring important adjustments at key historical moments, nevertheless remained a powerful component of Lakhnawi self-identity, as individuals and as constituent communities of an inclusive realm. 
21 As our earlier references to Lucknow's built environment have suggested, the changes in the physical fabric of the city reflected not only socio-economic changes taking place in the second half of the $19^{\text {th }}$ century among the city's residents, but also the impact of direct British rule on this urban centre. We can see this in both the actual urbanscape itself, but also in what the British called out as the significant places in the city (see Freitag 2014, 1989a). Indeed, by the 1870s, at least two competing understandings of Lucknow had emerged, one as the site of a continuing Successor-State styled cultural node (albeit with sub-narratives featuring different middle-class groups), and another as the premier site of the 1857 'Mutiny' and its British martyrs. Guidebooks created for British travellers to India depicted the 'Mutiny Trail' most dramatically: Murray's Guide (in its eighth edition in 1911), for instance, devoted one page to the history of the Nawabs and almost sixteen pages to 'Mutiny' history, accompanied by a special map focused on the key spots figuring in the repeated battles for the city waged during 1857-1858, with the Residency receiving the most intense attention.

In fascinating contrast to Murray's is the guidebook created in 1874 by Abbas Ali, who served as both darogah of a Lucknow imambara and also a ('pensioned') municipal engineer of the Public Works Department, turned photographer ('under the Patronage of His Honour the Lieutenant Governor of the N.W. Provinces and Oudh' as cited on the back of his carte de visite). So far as can be determined, this guidebook is the first to combine photographs with text and maps; called The Lucknow Album, it contains ' 50 photographic views of Lucknow and its environs'. As its introduction explains, it is aimed at both the touring audience of Britons and 'intelligent natives'. Accordingly, photographs include not only 'Mutiny' sites and Nawabi buildings, but bridges built by each (with an engineer's evaluations of the construction practices of each ruling entity). Most revealingly, it includes sites never before listed in guidebooks: sites that would have meaning for Indians, such as the shrine of Hazrat Abbas and the Talkatora Karbala grounds. It also includes a number of kothis, buildings often originally built by the Nawabs and their courtiers, then taken over by high-ranking Britons as residences and, by the end of the century, beginning to be repurposed: in several cases, their functions shifted into buildings serving modern and economic purposes, such as the Railway Administration office, and banks. Our argument would be that this guidebook's array of images represents the photographer's attempt to capture a third understanding of Lucknow-one that included 'traditional' buildings created by the Nawabs; sites significant to a larger and inclusive 'public' (including Muslims); and the buildings housing middle-class functions of a modernizing cultural system.

In support of this understanding of the nature of Lucknow's turn-of-the-century cultural system, we might note briefly two other collections of photographs produced by Abbas Ali. ${ }^{9}$ One was a reference work focused on the taluqdars (large landowners) and other elites of the area, with whom the Indian Civil Service staff would have to interact, The Illustrated Album of the Rajas and Taluqdars of Oudh. The audience for this volume was clearly British and Indian administrators of the Raj's north Indian bureaucracy. The other -The Beauties of Lucknow, with a text in Urdu-pictured actresses and courtesans of the city, still important figures in the perpetuation of the cultured life reflecting Nawabi style and values. The introduction to this volume makes clear it was aimed at a very different audience, made up primarily of those who still embraced the Lakhnawi cultural system, for whom these performers were immensely important. ${ }^{10}$ Taken altogether, the audiences addressed by these three volumes suggest to us the layering of many understandings of 
the city and how their advocates contributed actively to Lucknow's changing cultural system emerging around the turn of the century. The layers suggest Lucknow's capacity to adjust to changing circumstances while retaining the collective sense of its self and significance. Indeed, the repetition from one essay to the next in this collection, of the sense of Lucknow as distinctively inclusive (even if this attribute is lamented as decreasing) suggests both the informants' sense of their city and a historically validated characteristic of Lucknow as a particular urban place.

\section{$20^{\text {th }}$ Century Challenges and Lucknow's Cultural System}

This particular polycentric use of public spaces and multiple narratives concerning what matters, affecting how the past and the present should be understood, are unique to Lucknow but, still, are akin to experiences in other urban centres over the turn of the $20^{\text {th }}$ century, not least the movement from intra-community to inter-community conflict. It is worth noting for our purposes (and as a precursor to the information provided in the Introduction) that the distribution of urban centres in U.P. in the colonial period, and the proportion of the provincial population that could be termed urban, ${ }^{11}$ were unusual and may have led to the pattern of distinct urban styles that emerged in U.P. by the mid-19th century. Equally revealing is the pace of urbanization, for the number of urban centres increased substantially between 1850 and 1880 . By then the province contained over onethird of the largest cities (population greater than 250,000) in the subcontinent-more than any other province-and almost one-fifth of the next largest cities (100,000 to 250,000). Four of its five largest cities (the exception being Banaras, see Freitag 1989b) came to dominate the 'communal' history of the region.

The overall pattern, then, was similar throughout urban UP; what distinguished Lucknow from other cities was the way in which existing tensions became routed along conduits predominantly marked by Sunni-Shia conflict, rather than Hindu-Muslim (see Susewind in this volume for a contemporary example). When the next great outburst of Sunni-Shia conflict emerged in the late 1930s, the characteristics we saw for the early 1900s appeared to directly link those earlier protests with ones in the 1930s. These similarities, however, may distract us from the very different circumstances in which this second big protest took place. From dominance, the community now had to operate under parity. And, as the state structures shifted towards majority rule, Shias experienced more tenuous support from the government than previously. Significantly, however, these public recitations of verses (Shias used the verses to curse those responsible for killing Husain and his company) were not really aimed at the community of Others; in the changed and highly politicized context of the 1930s, both sets of protests were quite formally being staged as attacks against the government. A larger pattern in this period of change, then, was the shift from aiming protests at an Other community to protests about the perceived shortfall of 'government' efforts to protect minority interests. This was true whether 'government' was exercised by the British, a Maharaja, or an elected political party such as Congress.

That these ostensibly distinct targets could be used to comment on the inability of an unsympathetic state to protect varied community interests is one important measure of the changed perceptions expressed in public protest after numerous nationalist mobilizations. It also suggests a much larger gap between state and constituents, one that -at least in the 1930s-could not be filled by the Cultural-System glue of the locality. 
Mobilization, too, marked changed circumstances by the 1930s: such protests now appealed far beyond the particular urban place in which they occurred. Indeed, what was most alarming to authorities was the daily arrival of 'batch' after 'batch' of protestors traveling to support fellow Shias by joining the expressions of civil disobedience. ${ }^{12}$

Undoubtedly, experiences of staging the nationalist movement's myriad protests (joined during the early 1920s by the Khilafat Movement) had provided models for how public protests could be enacted. Even more importantly, these experiences had sharpened the perception that much of the problem between contending communities could be laid at the state's feet, though by now the 'state' was not so much British as it was Congress. Closer to the locality, the contestation reflected altered socio-political standing in the city, with the Sunnis now reaching beyond parity for their 'right' to religious freedom to recite madh-sohban ('attack' verses recited on street corners)-a right Sunnis had never previously been able to claim.

Writ large, these protests underscore the importance of communication networks in expanding notions of what constituted 'public interest'. Underscored, as well, was the significance of those issues when the call for action came to express, bodily and en masse, values understood to convey individual and collective identities. At the same time, such protests also bring our attention back to the specifics involved when bodies and buildings interact, in a specific set of urban spaces. The street corners on which protestors chanted their competing verses; the gates used to include and exclude particular groups; the city centre within and through which each group passed to physically express its claim on the city: all of these served as the stages on which identity-narratives and values could be enacted. This parallel may suggest to us that, in the face of a changing political system increasingly based on majority rule, minorities began to work to organize appeals that could bring outsiders to their cities for support in protests. In particular, flexible cultural systems were faced with very new kinds of demands as Partition lines were delineated, and mass population shifts occurred. How would all of these developments affect Lucknow's cultural system?

\section{Post-Independence Reworkings of the Cultural System}

As the range of essays here suggests, there are many ways we may examine the ongoing role played by Lucknow's cultural system in the post-independence period. Continuing our focus on the built environment, and how urban space is deployed for 'performing middle-classness' and related processes of identity-narrative expression, may help to suggest how history and anthropology contribute to an interdisciplinarity of understanding of these processes. Beginning with the implications for families of the imposition of boundary lines dividing British India into the two nation-states of India and Pakistan in 1947, recent scholars have looked especially at families and women in the massive transfers of population related to those lines (Zamindar 2010). For Lucknow, the very large number of refugees flooding into the city's environs made an immediate impact. Not least was the permanent alteration of Aminabad's park setting into 'a densely populated Shanty town, ${ }^{13}$ filled now by these refugees.

Outside of Delhi and Karachi, we still have too little systematic research to be able to grasp the full impact of these dramatic changes, beyond likely statistics of death and family dislocations (and, not least, the fate of women in areas subject to population movements). We do not yet understand, especially, the experiences of particular cities, 
including Lucknow, and the extent to which we can generalize regarding larger patterns. Not least of these experiences was the frequent assumption that if the family were labelled the minority community in each state (i.e. 'Muslim' in India or 'Hindu' in Pakistan), their claims to property were dangerously jeopardized. Only with systematic study can these phenomena be traced for Lucknow, but we do have evidence that suggests several developments that necessarily altered the fit between the built environment and the cultural system whose inclusive outlines had served Lucknow so well in the past.

31 Among the ethnographies included in this issue, we can see, especially, how reworkings of what it meant to be a Muslim (from 'cosmopolitanism' to 'Muslim middle-classness') or a Dalit (from 'Muslim' Lal Begi to 'Hindu' Valmiki) were being undertaken after Independence. The enactments of these changing identities certainly affected participation in educational systems (including access to school buildings, see Lee's article) and in consumption patterns, both of which affected how the groups experienced inclusiveness. Two other instances may be revealing, as well. Certain infamous examples may suggest the extremes of larger patterns, such as repurposing of imambaras and other significant buildings for goods storage and other prosaic (and ultimately detrimental) usages by newly arrived entrepreneurs after $1947 .{ }^{14}$ Only as the Archaeological Survey has intervened for careful restoration do legal issues about repurposing, as well as the impact of encroaching shops and residences, seem to have been addressed. Both the size and significant value of these properties have made their fate of great import, even without the symbolic and praxis issues embraced by Shias and others of Lucknow and beyond. That context is well explored in the essays collected here. Indeed, from the historian's perspective the varied strategies by which the actors identified here are reshaping Lucknow's inclusiveness are immensely revealing, be they those whose identitynarratives place them as new leaders with special skills (such as Arabic-speaking for Nadwa students, or Dalits/Valmikis seeking education, or middle-class Muslims pursuing globally recognized markers of their status).

In this larger cultural-system context, the prolonged court case and legislative follow-up regarding the holdings of the Raja of Mahmudabad, where the Government of India's seizure of 'evacuee properties' (which were then declared 'enemy properties' in the wake of the Indo-Pakistan War of 1965) should be seen as setting a pattern of making these properties available to others in Lucknow and elsewhere. ${ }^{15}$ Although the scale of these holdings make them unique, the larger processes of shifting property ownership and control to refugees and entrepreneurs-whether through direct ownership or through dramatically low rents that do not reflect property values-necessarily affected the close relationship between the values of Lucknow's cultural system and its use of built environments and other land usages, as well as its sense of inclusiveness. The Mahmudabad case study is especially important for us, since it is this family in particular that has contributed so much to perpetuating the cultural system's emphasis on Muharram and related public-space activities in maintaining a sense of enacted inclusiveness through Lucknow's long-lived style and far-reaching networks.

The flip side of these developments has been that post-partition newcomers would contribute substantively to the reworked cultural system, as the availability of such properties provided opportunities to establish both residential and business roots. Not least among these has been the renowned bookseller, Ram Advani, whose shop became an intellectual centre in Hazratganj, open to authors, students and public intellectuals alike 
(Ahmad 1997). We do not want to overlook the point that in all of these shifts, the active participation by Lakhnawis has been responsible for reshaping both local and far-flung understandings of the cultural system of the city, and the nature of its inclusiveness. Indeed, the longstanding value placed on 'inclusiveness' has enabled residents to expand the cultural definition of which groups could be included, as the social context shifted first from emphasis on courtly elites to middle classes, then to broadly defined members of a democracy.

It is impossible, with a focus on built environments, to ignore the impact in post-Partition UP (if not India as a whole) of the presence of a state government run by the Dalit party, BSP (Bahujan Samaj Party). As though taking up profound lessons from the Nawabi legacy in shaping this urban place, Mayawati's seven huge new parks and installations recognizing Dalit contributions have wrenched the map of Lucknow in very new directions, both literally and figuratively. With the exception of Parivartan Chowk, located within the city proper in the Kaiserbagh Historic District, these new built environments have pushed the city's outlines ever closer to the airport (Sinha \& Kant 2015). In these essays, an indication of this spatial shift is the new women's mosque constructed in the area near the airport-see Hong Tschalar's essay. Coupling these monumental government-sponsored BSP constructions with both the Lee and Hong Tschalar essays, then, we can see how additions to Lucknow's built environment still reflect the inclusiveness on which Lakhnawis pride themselves, now extended in a democracy to a greater reach that enables new claimants to public space and recognition. Moreover, we should certainly situate Mayawati's construction program within the larger frame of Hindutva's emphasis on near-by Ayodhya; it may even be possible to view these competing UP-based claims to cultural significance as parallel to the earlier competition between Lucknow and Banaras, where the strategies urged each other on.

\section{Conclusion}

This focus on built environments, then, should serve as a context for understanding the ethnographic examinations in this collection. Not least might be Taylor's study of Nadwa's increasingly central position, both in terms of geography and its intermediary role in bridging school and university, and/or training and professions, be they religious or linguistic (given the rare access to Arabic). Mayawati's architectural insistence on a place for Dalits ${ }^{16}$ might also be paired with the strategies of the Valmikis (examined by Lee) for moving themselves within the definition of state-approved identity: the two suggest differing but related ways that the inclusive propensity of the cultural system's inclusivity has provided precedents relating to both spatial statements and identitynarratives linking people to authenticity through place. And, finally, the insistence of Muslim women activists' assertions in public-spaces and through public media to gain recognition of place in Lucknow's cultural system also reflects earlier contestations around exercises in public.

These developments after 1947 suggest both continuities and significant disjunctures in the history of Lucknow. Among the continuities is the self-perception of Lakhnawis that they all help shape, through their participation, the distinctive cultural system that marks them out from residents of other cities. This leads to ongoing efforts by various marginalized groups to shift the understandings of whom and which values will be incorporated. That Lucknow is ever more tightly connected to other central places in the 
subcontinent and its larger global contexts also means, of course, that the fissiparous patterns that have so marked both the political and social history of India have affected developments in Lucknow as well. The impact of Hindutva as a political as well as social force cannot be denied. Yet Lucknow's cultural system has marked, as well as and more dramatically than almost anywhere else in the subcontinent, the very space that marks out the city itself. 'Inclusiveness' of the Lakhnawi cultural system has broadened fundamentally yet remains a significant characteristic of place.

\section{BIBLIOGRAPHY}

Ahmad, Imtiaz (1997) 'Through the Eye of a Street,' in Violette Graff (ed.), Lucknow: Memories of a City Oxford: Oxford University Press.

Bayly, Christopher Alan (1996) Empire and Information, Cambridge: Cambridge University Press.

Belli, Melia (2014) 'Mayawati's Lucknow: 'Making Subaltern Space in a Historic City', paper presented to the European Conference for South Asian Studies (ECSAS) at the University of Zurich in Zurich, Switzerland, July 24-27, 2014.

Fisher, Michael H. (1987) A Clash of Cultures, Delhi: Manohar Publications.

Freitag, Sandria (forthcoming) Acts of Seeing, Ways of Knowing.

Freitag, Sandria (2014) 'A Visual History of Three Lucknows,' South Asia, 37(3), pp. 431-45.

Freitag, Sandria (1989a) Collective Action and Community, Berkeley: University of California Press.

Freitag, Sandria (1989b) Culture and Power in Banaras, Berkeley: University of California Press.

Gell, Alfred (1998) Art and Agency, Oxford: Oxford University Press.

Hansen, Kathryn (1991) Grounds for Play, Berkeley: University of California Press.

Hasnain, Nadeem (forthcoming), An Ethnographical Study of Lucknow.

Sharar, Abdul Halim (1975 reprint) Lucknow: The Last Phase of an Oriental Culture, E. S. Harcourt \& F. Hussain, (eds.), New Delhi: Oxford University Press.

Jones, Justin (2012) Shia Islam in Colonial India, Cambridge: Cambridge University Press.

Khan, Muhammad Amir Ahmed (2014) 'Local Nodes of a Transnational Network,' Journal of the Royal Asiatic Society, Series 3, 24(3), pp. 397-413.

Llewellyn-Jones, Rosie (1993) A Fatal Friendship, Oxford: Oxford University Press.

Markel, Stephen \& Gude, Tushara Bindu (2010) India's Fabled City: The Art of Courtly Lucknow, New York: Prestel.

Oldenburg, Veena (1997) 'Lifestyle as Resistance,' in Violette Graff (ed.), Lucknow: Memories of a City, Oxford: Oxford University Press.

Pinney, Christopher \& Thomas, Nicholas (2001) Beyond Aesthetics, London: Bloomsbury Academic. Roberts, Emma (1835) Scenes and characteristics of Hindostan, London: William H. Allen Publishers. 
Sinha, Amita \& Kant, Rajat (2015) 'Mayawati and memorial parks in Lucknow, India,' Studies in the History of Gardens \& Designed Landscapes, 35(1), pp. 43-58.

Spate, O. H. K. \& Ahmad, Enayat (1950) 'Five cities of the Gangetic Plain,' The Geographical Review 40 , pp. 260-78.

Strulik, Stephanie (2014) ‘Modernization Means Pepsodent, Colgate, Closeup...,' paper presented to the Association for Asian Studies 2014 annual meeting, March 27-30, Philadelphia, PA.

Taj, Afroz (2007) The Court of Indar and the Rebirth of North Indian Drama, New Delhi: Anjuman Taraqqi Urdu (Hind).

Zamindar, Vazira Fazila-Yacoobali (2010) The Long Partition and the Making of Modern South Asia, New York: Columbia University Press.

\section{NOTES}

1. Key to this shared analytical space may be the Anthropology of Art argument about the meaning-making made possible as viewers brought their understandings of that image/built environment to the interaction itself. This theoretical approach began with the work of Alfred Gell, in his posthumously published work (1998). Since Gell had no time to reconsider or revise this seminal work, perhaps most useful for our purposes is the essay collection by his colleagues, Christopher Pinney and Nicholas Thomas (eds.) 2001.

2. The concept of an imambara thus meant that not only the large and decorative buildings constructed by the court or city elite could be imambaras, but that other city dwellers could devote a room in their house, no matter how modest, to this purpose as well.

3. 'Majority' and 'minority' are terms applied a bit anachronistically for this period, in order to provide a consistent conceptual framework to compare with patterns of the late $19^{\text {th }}$ century.

4. The conflict in early $20^{\text {th }}$ century Lucknow followed a pattern parallel to what had happened in cities like Bareilly and Agra, where intra-community tensions became routed to Hindu-Muslim conflict instead (Freitag 1989a).

5. See, e.g., Gooptu (2001), Chattapoadhyay (2005), and Nair (2011).

6. Akharas are used, for instance, by Sufis, musicians, wrestlers and medical practitioners for spiritual (and often professional) lineages or silsilahs marking fictive-kin connections among a leader/pir and the generation of followers. The term is also used as reference to the space used by the group, for instance, by wrestlers to compete.

7. Compare, for instance, the British treatment of Awadh (as described in works such as Fisher 1987) and that of Banaras described in Freitag (1989b). Some of the comparisons are also dealt with directly in Freitag's essay, in Nadeem Hasnain (ed.), forthcoming, ch. 1).

8. Bayly points out that such a 'literati' included Indo-Islamic notables and officers of state, many of whom were Hindus, especially Kayasths, Kashmiri Brahmins and Khattris. Indeed, Bayly terms Urdu-Hindustani a 'public tongue', a 'popular language spread by Sufi saints and Hindu devotees, [as well as] a language of the court and a discerning literati' (Bayly 1996: 193).

9. For examples of photographs from these three volumes, see especially Markel (2010: 21, 161, 162, 240).

10. The most obvious connector to this is Mirza Ruswa's novel Umrao Jan Ada; see also Hansen (1991) and Taj (2007).

11. Although no one centre can compare statistically with Calcutta, these trends refer to the province as a whole. See Spate \& Ahmad (1950). This article is also the source of the data that follows. 
12. Report by Lt.-Governor H. G. Haig on the Lucknow Madha Sahaba Controversy, British Library, India Office Records, L/P\&J/7, file 2587 for 1939, especially p. 10.

13. Thanks to anonymous reviewer no. 4 for this contribution.

14. For example, the Sibtainabad Imambara in Hazratganj, used by a firm of carpenters: it took several efforts at restoration, finally taken over by the ASI, to return it to its impressive state.

15. The holdings of Raja Mohammad Amir Ahmed Khan have certainly been the most celebrated of these cases because of the scale involved; when the Raja migrated to Pakistan in 1962, he had left his son and heir, and his wife, behind in Lucknow, as property owners of these immense holdings. Even after September 2005, when the court case aimed at restoring the properties to the present Raja was resolved in his favour by the Supreme Court of India, the Raja was prevented by an ordinance passed by the Government to nullify the Supreme Court decision. Such steps were taken by the Government of India to prevent a substantial impact on government as well as private citizens: Mahmudabad's holdings included half of Hazratganj Market, as well as bungalows occupied by various (BSP) state government officers. Mayawati's efforts to implement the Government's actions apparently included sealing of buildings and land to ensure that her government could gain possession of the buildings. Only after Prime Minister Manmohan Singh intervened in 2010 were the holdings finally secured to the Mahmudabad Raja.

16. Our understanding of Mayawati's impact on Lucknow has also been enhanced by Belli's paper presented with others in this collection to the European panel, 2014. Belli analyzed Lucknow's new Buddhist monuments as yet another political utilization of history. They replicated the design of India's oldest stupa, a Buddhist burial shrine, thus emplacing Dalits as heirs of India's lost Buddhist rulers. Dalit's political challenge to Hindu elites is also a cultural and architectural challenge.

\section{ABSTRACTS}

A new kind of cultural system emerged under the (Mughal) Successor State of Awadh that shaped especially its capital-city of Lucknow. The inclusiveness essential to claiming legitimacy by a Successor State not only helps to explain how this new Janus-faced kingdom could succeed, but enabled it to bequeath flexible strategies that worked for local urban dwellers under British imperial rule, and provided models of creativity for responding to altered contexts of life in contemporary India. This distinctive modality provides a range of socio-political, cultural, and economic attributes that are approached in complementary if distinctive ways by the disciplines of history and anthropology, as this collection of essays demonstrates very intriguingly. We treat here the emergence over time of key strategies, in their changing contexts, to chart characteristic practices and dynamics essential for this urban place.

\section{INDEX}

Keywords: Cultural System, Nawabs, built environment, interdisciplinarity, Successor States 
AUTHOR

SANDRIA FREITAG

Department of History, North Carolina State University 